\title{
Hypertension in relation to musculoskeletal disorders
}

\author{
J. S. LAWRENCE
}

From Abteilung für Rheumatologie und Balneologie der Medizinische Hochschule, Hannover, W. Germany

\begin{abstract}
Lawrence, J. S. (1975). Annals of the Rheumatic Diseases, 34, 451-456. Hypertension in relation to musculoskeletal disorders. Generalized osteoarthrosis was found to be significantly more common in older males with high than with low diastolic blood pressure. The excess of osteoarthrosis in those with hypertension was mainly in the hips, knees, carpometacarpal and metacarpophalangeal joints, and was independent of obesity in the hypertensive group. It was not associated with a higher cholesterol or uric acid level in the serum. Radiological evidence of avascular necrosis was present in $36 \%$ of males with osteoarthrosis of the hips and diastolic blood pressure above 100 $\mathrm{mmHg}$, in $20 \%$ with a diastolic pressure of $81-100 \mathrm{mmHg}$, but was found in none of those with osteoarthrosis and blood pressure of $80 \mathrm{mmHg}$ or below. Only those with osteoarthrosis and a diastolic pressure above $100 \mathrm{mmHg}$ had significantly more avascular necrosis than expected. Osteoarthrosis of the knee in females was more frequent in the hypertensive groups independent of obesity. It is concluded that vascular disorders are involved in this form of generalized osteoarthrosis.
\end{abstract}

An association between hypertension and rheumatic complaints has been postulated in the past. Fletcher and Lewis-Faning (1945) found hypertension in $42 \%$ of patients with osteoarthrosis but in only $9 \%$ of spondylitics and $17 \%$ of patients with rheumatoid arthritis. A separate rheumatic syndrome associated with hypertension, Hochblutdruckrheumatismus, was suggested by Bach (1935). He described a syndrome associated with high blood pressure in obese women characterized by vague rheumatic pain in the back and shoulders, radiating down the arms and thighs. These symptoms, which often disappeared completely in time, he attributed to impaired peripheral circulation. Porter (1942) also noted that $42 \%$ of women with a systolic pressure of $200 \mathrm{mmHg}$ or more (average diastolic pressure $117 \mathrm{mmHg}$ ) had aching pains in the limbs and back. Rubens-Duval, Villiaumay, Kaplan, and Brondani (1970) noted hypertension in half of those patients with generalized osteoarthrosis and obesity.

Since both hypertension and rheumatic disease, particularly osteoarthrosis, occur more frequently in older age groups, some degree of association is inevitable. However, in order to show a causal connexion, careful analysis of data from random population samples is required.

\section{Method}

Population samples for this study were examined in Leigh, Lancashire; Wensleydale, Yorkshire; Watford, Hertfordshire; the Rhondda and Vale of Glamorgan, South Wales; and in Jamaica. For a detailed description of the population samples see Bennett and Wood (1968).

All respondents completed a questionnaire on rheumatic complaints which were classified by site and duration of incapacity. The musculoskeletal system was examined and blood pressure estimated. Obesity was graded by the clinician on a $0-4$ scale. The relationship to weight and height was as follows.

Grade 4, weight $>24 \%$ above the mean for age, sex, and height.

Grade $3,11 \cdot 1 \%$ to $24 \%$ above the mean for age, sex, and height.

Grade 2, 5\% to $11 \%$ above the mean for age, sex, and height.

Grade $1,3 \cdot 6 \%$ below to $4 \cdot 9 \%$ above the mean for age, sex, and height.

Grade $0,>3 \cdot 6 \%$ below the mean for age, sex, and height.

Mean values were taken from the table in Abrahams and Widdowson (1940).

Routine $x$-rays were taken of the hands, feet, and cervical spine, and the knees and lumbar spine were examined in all populations except the Rhondda. A pelvic $x$-ray was 
taken in those aged 55 and over in Leigh, Wensleydale, and the Vale of Glamorgan, and from age 45 in Jamaica and Watford.

Blood samples were tested for rheumatoid factor (by Dr. J. Ball) on all surveys using the sheep-cell agglutination test (Ball, 1969), and for serum uric acid by the enzyme method of Liddle, Seegmiller, and Laster (1959), and for cholesterol (by the method of Sackett, 1925) on the Leigh, Wensleydale, Watford, and Jamaican samples (by Miss V. Hewitt).

In assessing the results a correction for age has been made by taking the mean of the values in each 5-year age group, those aged 75 and over being considered as one age group.

\section{Results}

\section{RHEUMATIC COMPLAINTS}

Rheumatic complaints were no more frequent in hypertensive individuals than in the population as a whole and such persons lost no more work time from musculoskeletal symptoms. Symptoms at the time of the survey were slightly, but not significantly, more common in the hypertensive females.

\section{OSTEOARTHROSIS}

Radiological evidence of osteoarthrosis was observed in at least one joint in $74-78 \%$ of males and $76-82 \%$ of females, but was unrelated to diastolic blood pressure (Table I). Generalized osteoarthrosis, defined as involvement of three or more joint groups, was how- ever significantly related in males to the diastolic pressure, though a graded relationship was found only in the older males. In males aged 60 and over the prevalence of generalized osteoarthrosis rose from $44-66 \%$ with increasing diastolic pressure. When males with generalized osteoarthrosis were divided into nodal and non-nodal forms, according to whether Heberden's nodes were present or not, it was found that only the non-nodal form showed a significant relationship to blood pressure. In females there was no significant relationship between generalized osteoarthrosis and blood pressure.

The excess of osteoarthrosis in the older males with hypertension was mainly in the hips, knees, metacarpophalangeal, and carpometacarpal joints (Fig. 1), and was significant only in these joints. This was not due to greater obesity in the hypertensive groups, since in the older males obesity was more common in the group with low blood pressure. There was a significantly greater prevalence of osteoarthrosis of the hips, for example, in nonobese males with a diastolic pressure above $80 \mathrm{mmHg}$ than in those with a pressure below this level. The impression gained was that osteoarthrosis was related both to hypertension and obesity, but that the two were independent.

In females there was a relationship between blood pressure and osteoarthrosis only in the knees, and this was present in both obese and nonobese females. Analysis showed that the relationship was present in each 5-year age group from 45 to 69.

Table I Relationship of blood pressure to osteoarthrosis in populations

\section{Diastolic blood pressure $(\mathrm{mmHg})$}

\begin{tabular}{l}
\hline Age $45+$ \\
-80 \\
$85-100$ \\
$>100$ \\
\hline Age $60+$ \\
-80 \\
$85-100$ \\
$>100$
\end{tabular}

\begin{tabular}{l}
\hline Age $60+$ without Heberden's nodes \\
-80 \\
$85-100$ \\
$>100$ \\
\hline Age $60+$ with Heberden's nodes \\
-80 \\
$85-100$ \\
$>100$
\end{tabular}

No. of joint groups with grade 2-4 osteoarthrosis (unweighted mean of five 5-year age groups from age 45-74 and one from 75+)

\begin{tabular}{|c|c|c|c|c|c|c|c|}
\hline \multicolumn{4}{|l|}{ Males } & \multicolumn{4}{|l|}{ Females } \\
\hline \multirow{2}{*}{$\begin{array}{l}\text { Total no. } \\
x \text {-rayed } \\
\text { and tested }\end{array}$} & \multicolumn{3}{|c|}{ Joint groups ( $\%)$} & \multirow{2}{*}{$\begin{array}{l}\text { Total no. } \\
x \text {-rayed } \\
\text { and tested }\end{array}$} & \multicolumn{3}{|c|}{ Joint groups $(\%)$} \\
\hline & $1+$ & $3+$ & $5+$ & & $1+$ & $3+$ & $5+$ \\
\hline $\begin{array}{l}356 \\
497 \\
212\end{array}$ & $\begin{array}{l}77 \\
78 \\
74\end{array}$ & $\begin{array}{l}31^{*} \\
41 \\
39\end{array}$ & $\begin{array}{l}16 \mathrm{NS} \\
20 \mathrm{NS} \\
22 \mathrm{NS}\end{array}$ & $\begin{array}{l}289 \\
511 \\
245\end{array}$ & $\begin{array}{l}76 \\
82 \\
82\end{array}$ & $\begin{array}{l}40 \text { NS } \\
45 \\
45\end{array}$ & $\begin{array}{l}23 \\
21 \\
21\end{array}$ \\
\hline $\begin{array}{r}96 \\
167 \\
85\end{array}$ & $\begin{array}{l}89 \\
90 \\
93\end{array}$ & $\begin{array}{l}44 \dagger \\
61 \\
66 \dagger\end{array}$ & $\begin{array}{l}25 \mathrm{NS} \\
33 \\
38\end{array}$ & $\begin{array}{r}93 \\
225 \\
135\end{array}$ & $\begin{array}{l}79 \\
80 \\
75\end{array}$ & $\begin{array}{l}70 \\
64 \\
72\end{array}$ & $\begin{array}{l}46 \\
41 \\
40\end{array}$ \\
\hline $\begin{array}{r}96 \\
167 \\
85\end{array}$ & $\begin{array}{l}60 \\
55 \\
57\end{array}$ & $\begin{array}{l}22 \dagger \\
33 \\
35\end{array}$ & $\begin{array}{l}10 \\
14 \\
11\end{array}$ & $\begin{array}{r}93 \\
225 \\
135\end{array}$ & $\begin{array}{l}29 \\
26 \\
27\end{array}$ & $\begin{array}{l}29 \\
26 \\
28\end{array}$ & $\begin{array}{l}18 \\
11 \\
16\end{array}$ \\
\hline $\begin{array}{r}96 \\
167 \\
85\end{array}$ & $\begin{array}{l}29 \\
34 \\
36\end{array}$ & $\begin{array}{l}22 \mathrm{NS} \\
28 \\
31\end{array}$ & $\begin{array}{l}15 \mathrm{NS} \\
19 \\
26 \mathrm{NS}\end{array}$ & $\begin{array}{r}93 \\
225 \\
135\end{array}$ & $\begin{array}{l}50 \\
54 \\
48\end{array}$ & $\begin{array}{l}41 \text { NS } \\
38 \\
44\end{array}$ & $\begin{array}{l}28 \\
30 \\
24\end{array}$ \\
\hline
\end{tabular}

NS $=P>0.05 ; * P<0.01 ; \dagger P \simeq 0.03$ 


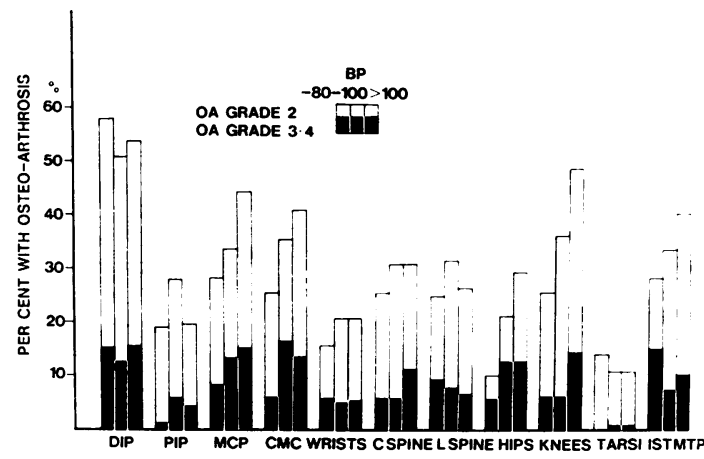

FIG. 1 Relationship of joint pattern of osteoarthrosis to diastolic blood pressure in males aged $60+$

\section{AVASCULAR NECROSIS}

In our population samples we have graded all hip and knee $x$-rays for avascular necrosis on a $0-4$ scale (Fig. 2). Of the eleven males aged 60 and over with osteoarthrosis of the hip and a diastolic blood pressure of over $100 \mathrm{mmHg}$, four $(36 \%)$ had radiological evidence of avascular necrosis. Four $(20 \%)$ of the 20 males with osteoarthrosis of the hip, aged 60 or over and a diastolic pressure of $81-100 \mathrm{mmHg}$, had similar changes. None of the five with osteoarthrosis and a diastolic pressure up to $80 \mathrm{mmHg}$ had evidence of avascular necrosis. The frequency of grade 3-4 avascular necrosis was $27 \%, 10 \%$, and $0 \%$, respectively, in the blood pressure groups. Only those with osteoarthrosis and a diastolic pressure over 100 mmHg had significantly more avascular necrosis than the $2 \cdot 8 \%$ with grade $3-4$ avascular necrosis expected in males aged $60+$.
In females an association appears to exist mainly in the knees, there being a significant relationship between diastolic blood pressure and osteonecrosis in the femoral condyles after correction for age. $4 \%$ of females (aged 45+) with a diastolic pressure below $80 \mathrm{mmHg}$ had radiological evidence of osteonecrosis compared with $7 \%$ of those with a blood pressure of $85-100 \mathrm{mmHg}$, and $10 \%$ of those with a diastolic blood pressure over $100 \mathrm{mmHg}$. This relationship though insignificant at the $2 \%$ level, was not present in males.

\section{DISC DEGENERATION}

A comparison of disc degeneration and blood pressure in each age group from 45 upwards showed a relationship in both the cervical and lumbar spine (Table II). It was significant only in males and was most marked in the lumbar spine. In both the lumbar and cervical spine in males grade 2 disc degeneration was associated with hypertension, but grade 3-4 was not. The association is thus with osteophyte formation but not with disc narrowing, since a grading of 3 or 4 was not given unless there was substantial disc narrowing.

Since grade 2 disc degeneration is easily confused with the early stages of ankylosing hyperostosis, the prevalence of the latter condition in persons with and without hypertension was estimated but no significant association observed.

\section{RHEUMATOID ARTHRITIS}

The prevalence of rheumatoid arthritis was $2 \%$ in males and $6 \%$ in females in the normotensive group (Table III), and $1.5 \%$ in males and $6.7 \%$ in females
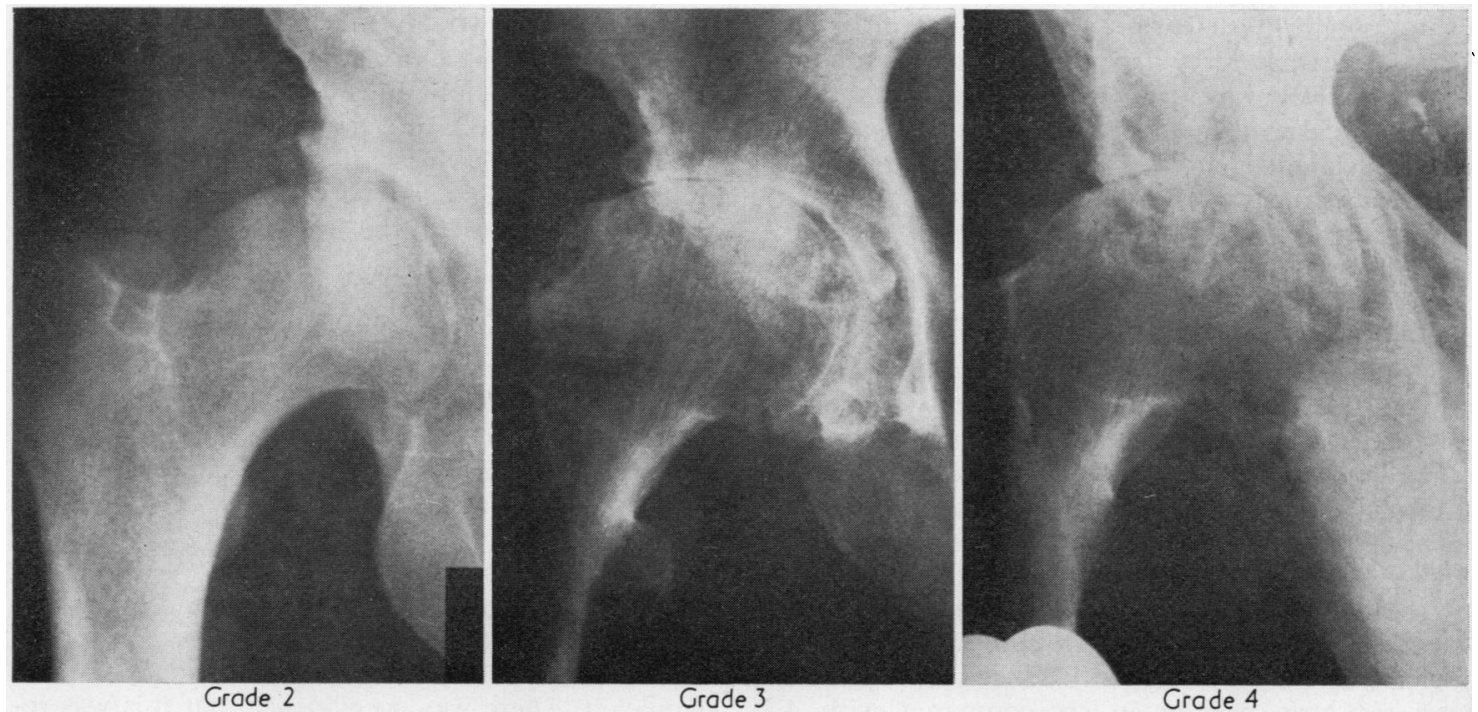

FIG. 2 Grades of avascular necrosis 
Table II Relationship of diastolic blood pressure to percentage with disc degeneration in the population aged 45 and over

\begin{tabular}{|c|c|c|c|c|c|c|c|c|c|c|c|c|c|c|}
\hline \multirow{4}{*}{$\begin{array}{l}\text { Diastolic } \\
\text { BP }(\mathrm{mmHg})\end{array}$} & \multicolumn{14}{|c|}{ Grade of disc degeneration } \\
\hline & \multicolumn{6}{|l|}{ Males } & \multicolumn{8}{|l|}{ Females } \\
\hline & \multicolumn{3}{|c|}{ Lumbar (\%) } & \multicolumn{3}{|c|}{ Cervical (\%) } & \multicolumn{4}{|c|}{ Lumbar $(\%)$} & \multicolumn{4}{|c|}{ Cervical (\%) } \\
\hline & $\begin{array}{l}\text { Total no. } \\
x \text {-rayed }\end{array}$ & 2 & $2-43-4$ & $\begin{array}{l}\text { Total no. } \\
x \text {-rayed }\end{array}$ & 2 & $2-43-4$ & $\begin{array}{l}\text { Total no. } \\
x \text {-rayed }\end{array}$ & 2 & $2-4$ & $3-4$ & $\begin{array}{l}\text { Total no. } \\
x \text {-rayed }\end{array}$ & 2 & $2-4$ & 3 \\
\hline $\begin{array}{l}-80 \\
85-100 \\
>100\end{array}$ & $\begin{array}{r}265 \\
259 \\
83\end{array}$ & $\begin{array}{l}43^{*} \\
49 \\
60^{*}\end{array}$ & $\begin{array}{l}73 \dagger 29 \\
75 \\
88 \dagger 26 \\
89\end{array}$ & $\begin{array}{l}351 \\
495 \\
211\end{array}$ & $\begin{array}{l}26^{*} \\
30 \\
36^{*}\end{array}$ & $\begin{array}{l}74 \ddagger 48 \\
7444 \\
81 \ddagger 45\end{array}$ & $\begin{array}{l}232 \\
347 \\
172\end{array}$ & $\begin{array}{l}44 \\
43 \\
49\end{array}$ & $\begin{array}{l}61 \mathrm{NS} \\
62 \\
67 \mathrm{NS}\end{array}$ & $\begin{array}{l}17 \\
19 \\
18\end{array}$ & $\begin{array}{l}287 \\
507 \\
245\end{array}$ & $\begin{array}{l}35 \\
33 \\
35\end{array}$ & $\begin{array}{l}68 \\
67 \\
65\end{array}$ & $\begin{array}{l}33 \\
34 \\
30\end{array}$ \\
\hline
\end{tabular}

$* P \simeq 0.01 ;+P<0.01 ; \ddagger P \simeq 0.04 ; N S=P>0.05$.

Percentages are unweighted means of seven 5-year age groups.

Table III Relationship of diastolic pressure to indices of rheumatoid arthritis in adults aged $15+$ (unweighted mean of 6 age groups)

\begin{tabular}{|c|c|c|c|c|c|c|c|c|}
\hline \multirow{3}{*}{$\begin{array}{l}\text { Diastolic } \\
\text { pressure } \\
(\mathrm{mmHg})\end{array}$} & \multicolumn{3}{|c|}{ Clinical rheumatoid arthritis } & \multicolumn{3}{|c|}{$\begin{array}{l}\text { Radiological evidence of } \\
\text { erosive arthritis of hands or feet }\end{array}$} & \multicolumn{2}{|c|}{ Positive SCAT } \\
\hline & \multirow{2}{*}{$\begin{array}{l}\text { Total no. } \\
\text { examined }\end{array}$} & \multicolumn{2}{|c|}{ Grade (\%) } & \multirow{2}{*}{$\begin{array}{l}\text { Total no. } \\
x \text {-rayed }\end{array}$} & \multicolumn{2}{|c|}{ Grade (\%) } & \multirow{2}{*}{$\begin{array}{l}\text { Total no. } \\
\text { tested }\end{array}$} & \multirow{2}{*}{$\begin{array}{l}\text { Positive at titre of } 1: 32 \\
(\%)\end{array}$} \\
\hline & & $2-4$ & $3-4$ & & $2-4$ & $3-4$ & & \\
\hline $\begin{array}{l}\text { Males } \\
-80 \\
85-100 \\
>100\end{array}$ & $\begin{array}{l}899 \\
841 \\
255\end{array}$ & $\begin{array}{l}2 \cdot 0 \\
4 \cdot 1 \\
1 \cdot 5\end{array}$ & $\begin{array}{l}0.3 \\
2 \cdot 5 \\
0.6\end{array}$ & $\begin{array}{l}873 \\
831 \\
249\end{array}$ & $\begin{array}{l}5 \cdot 0 \\
5 \cdot 1 \\
3 \cdot 1\end{array}$ & $\begin{array}{l}0.6 \\
1.8 \\
0.7\end{array}$ & $\begin{array}{l}861 \\
816 \\
246\end{array}$ & $\begin{array}{l}3 \cdot 0 \\
4 \cdot 3 \\
1 \cdot 7\end{array}$ \\
\hline $\begin{array}{c}\text { Females } \\
\begin{array}{c}-80 \\
85-100 \\
>100\end{array}\end{array}$ & $\begin{array}{l}833 \\
719 \\
267\end{array}$ & $\begin{array}{l}6 \cdot 0 \\
4 \cdot 9 \\
6 \cdot 1\end{array}$ & $\begin{array}{l}1 \cdot 7 \\
0 \cdot 8 \\
1 \cdot 7\end{array}$ & $\begin{array}{l}820 \\
712 \\
262\end{array}$ & $\begin{array}{l}3 \cdot 6 \\
3 \cdot 8 \\
4 \cdot 7\end{array}$ & $\begin{array}{l}0.7 \\
0.7 \\
0.6\end{array}$ & $\begin{array}{l}773 \\
681 \\
247\end{array}$ & $\begin{array}{l}3 \cdot 4 \\
4 \cdot 6 \\
1 \cdot 8\end{array}$ \\
\hline
\end{tabular}

in those with hypertension after correction for age. There was thus no evidence of either a positive or negative relationship between these two conditions. Radiological evidence of erosive arthritis was similarly unrelated. There was a tendency towards somewhat lower titres of rheumatoid factor in the hypertensive individuals but the difference was not significant $(\mathrm{P}=\mathbf{0 . 0 8})$.

\section{ISCHAEMIC HEART DISEASE}

Routine electrocardiograms of 124 males and 38 females from the Rhondda and Jamaica were consistent with the Minnesota coding (Rose and Blackburn, 1966) for probable or possible coronary artery disease. Nine had clinical evidence of rheumatoid arthritis (grade 2-4), eight minimal and one moderate compared with 10.7 expected. Eleven had erosive arthritis of the hands or feet on $x$-ray compared with 13.1 expected. It was present both clinically and radiologically in only one. A positive sheep-cell agglutination test was present in six compared with $\mathbf{4 . 2}$ expected.
SERUM URIC ACID LEVELS

Levels were high in more subjects and low in fewer of those with diastolic pressures above $100 \mathrm{mmHg}$, but the differences were not significant. The data were derived only from the Leigh, Wensleydale, Watford and Jamaican surveys since serum uric acid was not tested in the Rhondda or Glamorgan surveys.

There was no evidence that the generalized osteoarthrosis encountered in hypertensive males is secondary to high urate concentrations. In this series a serum urate level greater than $0.357 \mathrm{mmol} / 1(6 \mathrm{mg} /$ $100 \mathrm{ml}$ ) was found in $11 \%$ of hypertensive males with generalized osteoarthrosis and in the same proportion of normotensive arthrotic males.

SERUM CHOLESTEROL

Serum cholesterol levels showed some relationship to blood pressure in males under the age of 65 $(P \simeq 0.02)$, but a similar trend in older females was not significant. There was no evidence that this was related to the occurrence of osteoarthrosis. 
OBESITY

Although the more severe grades of obesity were twice as common in individuals with generalized osteoarthrosis, obesity was not a particular feature of the generalized osteoarthrosis of elderly males with hypertension, only $33 \%$ of whom were obese compared with $30 \%$ of hypertensives without generalized osteoarthrosis (Table IV). Rather, obesity was a feature of those with generalized osteoarthrosis and normal blood pressure, of whom $19 \%$ were moderately or grossly obese compared with $5 \%$ of normotensives without generalized osteoarthrosis. Rheumatic complaints in obese persons of both sexes at the time of the survey were significantly more frequent than expected (Table V).

\section{Discussion}

The present data appear to negate the concept of hypertensive rheumatism as a separate entity, in which rheumatic complaints arise in the absence of connective tissue disease. Nor do they lend support to a syndrome comprising obesity and hypertension as postulated by Bach (1935) and Ellman (1936). Musculoskeletal symptoms are more frequent in obese persons, regardless of the blood pressure; and a particular form of osteoarthrosis is more frequent in hypertensive subjects regardless of the body weight. This is not the primary generalized form of osteoarthrosis described by Kellgren and Moore (1952), of which Heberden's nodes are such a prominent feature: this nodal form is more common in women and arises at about the time of the menopause. The non-nodal form belongs to a heterogeneous group which may be classified as non-nodal generalized osteoarthrosis. This is more common in males and two main types have already been described, one
Table $\mathrm{V}$ Rheumatic complaints in obese persons aged 45+

\begin{tabular}{|c|c|c|c|c|}
\hline & \multicolumn{3}{|c|}{ Pain at any time } & \multirow{3}{*}{$\begin{array}{l}\text { Pain at } \\
\text { time of } \\
\text { survey }\end{array}$} \\
\hline & \multirow{2}{*}{$\begin{array}{l}\text { Total } \\
\text { with pain }\end{array}$} & \multicolumn{2}{|c|}{ off work } & \\
\hline & & $1 w+$ & $3 m+$ & \\
\hline \multicolumn{5}{|l|}{$\begin{array}{l}\text { Males } \\
(n=217)\end{array}$} \\
\hline $\begin{array}{l}\text { Observed } \\
\text { Expected }\end{array}$ & $170^{*}$ & 70 & 34 & $89+$ \\
\hline $\begin{array}{l}\text { Expected } \\
\text { Females } \\
(\mathrm{n}=392)\end{array}$ & $155^{*}$ & 60 & 24 & 69T \\
\hline Observed & 325 & 91 & 43 & $215 \dagger$ \\
\hline Expected & 316 & 96 & 39 & $187 \dagger$ \\
\hline
\end{tabular}

occurring after attacks of inflammatory polyarthritis and involving mainly the metacarpophalangeal joints, and the other occurring in individuals with hyperuricaemia and having no specific pattern of joint involvement (Kellgren, Lawrence, and Bier, 1963; Lawrence, 1969).

The present study indicates that there is a third form occurring mainly in males over the age of 60 and associated with hypertension. In this form, the hips, knees, carpometacarpal and metacarpophalangeal joints are mainly affected, but a significant feature is increased osteophyte formation in the spine which is not associated with disc narrowing and appears to be independent of disc degeneration or ankylosing hyperostosis.

Experimental evidence for an association between ischaemia and osteophyte formation is forthcoming from the work of Goldhaft, Wright, and Pemberton (1933). They were able by ligating the patellar artery

Table IV Relationship of obesity to osteoarthrosis and blood pressure in males aged 60+

\begin{tabular}{|c|c|c|c|c|c|c|c|c|}
\hline \multirow[b]{3}{*}{$\begin{array}{l}\text { Total no. and diastolic } \\
\text { pressure }(\mathrm{mmHg})\end{array}$} & \multicolumn{8}{|c|}{ No. of joint groups with grade 2-4 osteoarthrosis } \\
\hline & \multicolumn{4}{|l|}{$0-2$} & \multicolumn{4}{|l|}{$3+$} \\
\hline & $\begin{array}{l}\text { Total } \\
\text { no. }\end{array}$ & -80 & $85-100$ & $>100$ & $\begin{array}{l}\text { Total } \\
\text { no. }\end{array}$ & -80 & $85-100$ & $>100$ \\
\hline $\begin{array}{l}\text { Grade of obesity } \\
(+ \text { no examined }) \\
0(188) \\
1(56) \\
2(46) \\
3(48) \\
4(4) \\
2-4 \\
3-4 \text { Unweighted mean } \\
\quad \text { of } 4 \text { age groups }\end{array}$ & $\begin{array}{c}108 \\
27 \\
28 \\
17 \\
1 \\
25 \% \\
10 \% *\end{array}$ & $\begin{array}{l}41(22 \%) \\
7 \\
7 \\
3 \\
0 \\
17 \% \\
5 \% \\
5 \%\end{array}(10 \%)$ & 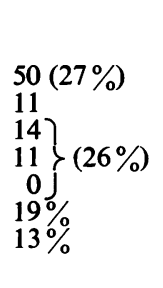 & $\begin{array}{l}\left.\begin{array}{l}17(9 \%) \\
9 \\
7 \\
3 \\
1\end{array}\right\}(11 \%) \\
30 \% \\
11 \%\end{array}$ & $\begin{array}{l}80 \\
29 \\
18 \\
31 \\
3 \\
32 \% \\
21 \% *\end{array}$ & $\left.\begin{array}{l}18(10 \% \mathrm{NS}) \\
6 \\
5 \\
6 \\
1\end{array}\right\}(12 \% \mathrm{NS})$ & $\begin{array}{l}\begin{array}{l}36 \\
17 \\
9 \\
14 \\
1 \\
1 \\
31 \% \\
19 \%\end{array}(24 \%) \\
\text { J }\end{array}$ & $\begin{array}{l}26(14 \%) \\
6 \\
4 \\
11 \\
1 \\
33 \% \\
25 \%\end{array}$ \\
\hline Total (342) & 181 & 58 & 86 & 37 & 161 & 36 & 77 & 48 \\
\hline
\end{tabular}

$* \mathbf{P}<0.01$. 
in dogs to produce proliferation of bone at the tendinous attachments, or at the base of the cartilage, resembling osteoarthrosis. The changes produced in young animals were discrete, while in older animals they were clearer and more manifest. This is consistent with our finding of increased osteophyte formation on the vertebral bodies.

Atherosclerosis and subchondral ischaemia, once considered to be the cause of degeneration of cartilage are not believed to be significant since articular chondrocytes overlying infarcted bones retain their viability (Sokoloff, 1969). The possibility remains that avascular necrosis may have played a part in the development of osteoarthrosis by altering the mechanics of joints, particularly in middle-aged males.

Watson-Jones (1962) has pointed out that in monarticular osteoarthrosis of the hip the radiological appearances are similar to those of avascular necrosis with secondary arthrosis occurring after dislocation of the joint. There is the same mottling, irregular density, cyst formation, narrowing of the joint space, and flattening of the contour of the head. At opera- tion, areas of avascular necrotic bone and articular cartilage are evident. Saville and Dickson (1968) consider that in $10 \%$ of males and $4 \%$ of females with osteoarthrosis of the hip the condition is secondary to nontraumatic osteonecrosis, and further, Susta, Streda, and Pazderka (1971) observed the histological pattern of osteonecrosis in $60 \%$ of cases. Evidence that ischaemia in the femoral head plays a part in osteoarthrosis of the hip is confirmed by iodide clearance rates (Hernborg, 1969). The present study further confirms these views and indicates that hypertensive vascular disease is associated with a generalized form of osteoarthrosis in older males. In females the condition appears to be more localized. It is of interest that in the present population samples the knee was the only joint to have an increased prevalence of osteoarthrosis in hypertensive nonobese females.

I am indebted to Dr. W. E. Miall for facilities granted in Jamaica and for much helpful advice and criticism; and to Miss V. Hewitt for data on serum uric acid and cholesterol levels.

\section{References}

Abrahams, M., AND Widdowson, E. M. (1940) in 'Modern Dietary Treatment', Tables, p. 364. Baillière, Tindall and Cox, London

BACH, F. (1935) 'General investigation of the patient' in 'The Rheumatic Diseases', p. 65. Cassell, London

BALL, J. (1969) 'Tests for R.A.', in 'Copeman's Textbook of the Rheumatic Diseases', p. 894. Livingstone, Edinburgh

BennetT, P. H., AND Wood, P. H. N. (1968) 'Outline details of general population surveys reported at the symposium' in 'Population Studies of the Rheumatic Diseases', p. 469. Excerpta Medica Foundation, Amsterdam

Ellman, P. (1936) Postgrad. med. J., 12, 211 (Chronic rheumatic joint disease in general practice)

Fletcher, E., AND Lewis-Faning, E. (1945) Postgrad med. J., 21, 54 (Chronic rheumatic diseases: statistical study of 1000 cases)

Goldhaft, A. D., Wright, L. M., And Pemberton, R. (1933) Ann. intern. Med., 6, 1591 (Influence of age in experimental production of hypertrophic arthritis)

Hernborg, J. (1969) Arthr. and Rheum., 12, 30 (Elimination of $\mathrm{Na}^{131}$ I from the head and neck of the femur in unaffected and osteo-arthritic hip joints)

Kellgren, J. H., AND MoORe, R. (1952) Brit. med. J., 1, 181 (Primary generalised osteo-arthritis)

- LaWrence, J. S., AND Bier, F. (1963) Ann. rheum. Dis., 22, 237 (Genetic factors in generalised osteoarthrosis)

LAWRENCE, J. S. (1969) Amer. J. Epidem., 90, 381 (Generalized osteo-arthrosis in a population sample)

Liddle, L., Seegmiller, J. E., AND Laster, L. (1959) J. Lab. clin. med., 54, 903 (The enzymatic spectrophotometric method for the determination of serum uric acid)

Porter, E. (1942) Postgrad. med. J., 12, 80 (Hypertension in women)

Rose, G. A., AND BLACKBURN, H. (1966) 'Classification of the electrocardiogram for population studies', Monograph 56 in 'Cardiovascular Survey: Methods', p. 137. World Health Organization, Geneva

Rubens-Duval, A., Villiaumay, J., Kaplan, G., and Brondani, J-C. (1970) Rev. Rhum. 37, 129 (Aspects cliniques de la maladie arthrosique)

SACKetT, G. E. (1925) J. biol. Chem., 64, 203 (Modification of Bloor's method for the determination of cholesterol)

Saville, P. D., ANd Dickson, J. (1968) Arthr. and Rheum. 11, 635 (Age and weight in osteoarthritis of the hip)

SoKoloff, L. (1969) 'The pathology of degenerative joint disease' in 'The Biology of Degenerative Joint Disease', p. 13. University of Chicago Press, Chicago and London

Susta, A., STreda, A., And Pazderka, V. (1971) 'Comparison of the clinical and X-ray pattern of OA and the histological findings', in 'VII European Rheumatology Congress, Abst. 84'. British Branch of European League against Rheumatism, London

WATSON-JONES, R. (1962) ‘Avascular necrosis of bone' in 'Fractures and Joint Injuries', p. 73. Livingstone, Edinburgh 